\title{
Pengembangan Bahan Ajar Teks Cerita Panji Berbasis Content Language Integrated Learning (CLIL) untuk SMK
}

\author{
${ }^{1}$ Sri Utami, ${ }^{2}$ Lailiyatus Sa'diyah \\ ${ }^{1,2}$ Universitas Nahdlatul Ulama Blitar, Indonesia \\ Email: ${ }^{1}$ utami3215@gmail.com, ${ }^{2}$ lailiyatus_Sadiyah@yahoo.com
}

\begin{tabular}{l}
\hline Tersedia Online di \\
\hline http://www.jurnal.unublitar.ac.id/ \\
index.php/briliant \\
\hline Sejarah Artikel \\
\hline Diterima pada 29 Oktober 2019 \\
Disetuji pada 27 November 2020 \\
Dipublikasikan pada 29 Februari \\
2020 Hal. 27-35 \\
\hline Kata Kunci: \\
\hline Bahan Ajar, Cerita Panji, CLIL \\
\hline DOI \\
\hline http://dx.doi.org/10.28926/briliant. \\
v4i4.379
\end{tabular}

\begin{abstract}
Abstrak: Penelitian ini merupakan inovasi yang mengintegrasikan budaya Indonesia (Cerita Panji) dengan teori perkembangan bahasa yang telah diterapkan di dunia, CLIL. Secara khusus, penelitian ini bertujuan: (1) menciptakan bahan ajar Cerita Panji bermuatan CLIL; (2) mendeskripsikan kelayakan bahan ajar Cerita Panji bermuatan CLIL. Penelitian ini didasarkan pada model penelitian R\&D dengan menerapkan lima dari sepuluh tahap. Penelitian ini dianalisis secara kuantitatif dan kualitatif. Data kuantitatif berupa skor penilaian oleh validator ahli, guru bahasa Indonesia SMK, dan peserta didik kelas $\mathrm{X}$ SMK. Data kualitatif berupa komentar yang dikemukakan validator ahli, guru bahasa Indonesia SMK, dan peserta didik kelas X SMK. Berdasarkan data tersebut, bahan ajar ini layak diimplementasikan dalam pembelajaran di SMK.
\end{abstract}

\section{PENDAHULUAN}

Bahan ajar Cerita Panji merupakan sebuah inovasi pengembangan bahan ajar sastra di SMK. Bahan ajar ini disusun berdasarkan muatan pembelajaran sastra di kelas X SMK yang minim. Genre teks yang dipelajari siswa di kelas X berjumlah delapan teks, berupa teks laporan hasil observasi, teks eksposisi, teks anekdot, teks cerita rakyat, teks negosiasi, teks debat, teks biografi, dan teks puisi. Dari delapan genre teks yang dipelajari, hanya terdapat dua genre teks bermuatan sastra yang dipelajari siswa, yaitu teks cerita rakyat dan puisi. Muatan sastra yang minim tersebut akan berdampak pada kemampuan mengapresiasi. Hal ini didukung oleh pernyataan Haryani (2018) bahwa embelajaran sastra di sekolah diakui masih sangat minim dan kurang aktraktif. Kenyataan ini berdampak pada lemahnya apresiasi dan penghargaan peserta didik terhadap karya sastra. Oleh karena itu, muatan sastra SMK yang minim menuntut adanya suatu inovasi yang mengangkat suatu kebudayaan menuju masyarakat global. Cerita Panji inilah yang selanjutnya diangkat menjadi bahan ajar sastra di SMK. 
Penyampaian budaya yang diintegrasikan dalam pembelajaran bahasa dan sastra diciptakan melalui produk bahan ajar ini, sehingga mudah untuk digunakan guru dan siswa. Selaras dengan Prastowo (dalam Pratiwi, 2015: 19) yang menyatakan terkait bahan ajar sebagau segala bahan (baik informasi, alat, maupun teks) yang disusun secara sistematis, yang menampilkan sosok utuh dari kompetensi yang akan dikuasai peserta didik dan digunakan dalam proses pembelajaran dengan tujuan perencanaan dan penelaahan implementasi pembelajaran.

Kehadiran Cerita Panji sebagai bahan ajar sastra di SMK merupakan upaya untuk mempertegas budaya lokal dalam pembelajaran sastra SMK, sekaligus mengantarkan menuju era globalisasi. Selain itu, sebagai upaya untuk menumbuhkan budi pekerti peserta didik dan meningkatkan kualitas SDM di Jawa Timur, khususnya mewujudkan Nawacita melalui pengembangan pendidikan dan kebudayaan.

Cerita klasik pada Cerita Panji bukan saja menyangkut sastra lokal tetapi mengaitkan komponen arkeologi, sejarah, pertanian, antropologi, politik, budaya, dan komponen arkeologi yang luas (Manuaba, 2013: 57). Nilai universal yang terkandung pun layak dipelajari untuk memperbaiki kualitas sifat dan perilaku siswa, menumbuhkan rasa cinta pada bumi kelahiran, dan memupuk kecintaan terhadap tanah air. Hal ini selaras juga dengan tujuan akhir dari pembelajaran budaya, khususnya sastra di SMK berupa pelibatan kajian nilai budaya, kepribadian, estetik, dan sosial untuk peserta didik. (Kemendikbud, 2016: viii). Cerita Panji juga menjadi ikon di Jawa Timur melalui Program Konservasi Budaya Panji yaitu wujud konkret dari serangkaian kegiatan bertemakan cerita Panji yang dianggap sebagai pusaka warisan budaya Indonesia. Peserta didik SMK dapat memperluas pengetahuan budayanya, kemudian mengaplikasikan nilai-nilai kehidupan yang memuat budayanya sesuai dengan jati diri SMK yang berjiwa entrepreneurship.

Sebuah penelitian yang dilakukan Philipus Nugroho Hari Wibowo tahun 2018 berjudul Kisah Panji pada Relief Candi sebagai Inspirasi Penciptaan Film merupakan sebuah adaptasi Cerita Panji dalam relief yang diubah menjadi sebuah film perjalanan. Selain itu, Widya Dutha tahun 2017 mengembangkan model wisata budaya berbasis cerita panji yang memuat tiga aspek, yaitu (1) seni pertunjukan topeng dengan artefak, (2) Heritage Performing Art di candi atau situs, dan (3) archaeological trail di Gunung Penanggungan. Indri Setyoningrum pada 2018 berjudul Transformasi Etika Cerita Panji Dalam Masyarakat Jawa Dan Pemanfaatannya Sebagai Bahan Ajar Bahasa Indonesia menunjukkan bahwa Cerita Panji dimanfaatkan dalam pembelajaran teks ulasan di SMP. Oleh karena itu, penelitian ini melakukan inovasi melalui pengembangan bahan ajar dengan muatan Cerita Panji untuk SMK.

Kompetensi dasar yang dikembangkan menjadi bahan ajar bahasa Indonesia kelas X di SMK meliputi aspek pengetahuan dan aspek keterampilan. Kompetensi dasar aspek pengetahuan yaitu mendeskripsikan nilai-nilai dan isi yang terkandung dalam cerita rakyat baik lisan maupun tulis (KD 3.7). Adapun kompetensi dasar aspek keterampilan berupa menceritakan kembali isi cerita rakyat yang didengar dan dibaca (KD 4.7). Kedua aspek tersebut dikembangkan 
menjadi suatu bahan ajar dengan pendekatan Content Language Integrated Learning.

Penyusunan bahan ajar Cerita Panji diintegrasikan pula dengan pendekatan CLIL yang menjadi dasar pengembangan kurikulum bahasa Indonesia pada kurikulum terbaru di Indonesia. The interrelationship between the $4 C s$ (Content, Communication, Cognition and Culture) is thought to lead to effective CLIL. (Vázquez, 2013: 72-73). Keutuhan perencanaan pembelajaran bahasa dengan CLIL ini, selain memfasilitasi pembelajaran, juga dapat membantu guru dalam belajar bahasa, khususnya sastra Indonesia.

Hasil pengembangan produk berupa bahan ajar teks cerita Panji berorientasi pendekatan Content Language Integrated Learning (CLIL) telah menyumbangkan kekosongan bahan ajar sastra berupa teks cerita rakyat, khususnya cerita Panji yang menjadi budaya masyarakat di Kediri dan Jawa Timur pada umumnya. Bahan ajar teks cerita panji untuk SMK Kelas X juga telah dapat digunakan oleh guru bahasa Indonesia dalam membelajarkan aspek pengetahuan mengidentifikasi nilai-nilai cerita Panji dan keterampilan berbahasa yang mendekatkan bahasa dengan budaya peserta didik.

\section{METODE}

Metode pengembangan ini mengadaptasi Research and Development $(R \& D)$ dari Borg dan Gall, yaitu penelitian yang digunakan untuk menghasilkan produk tertentu, dan menguji keefektifan produk tertentu (Sugiyono, 2014: 407). Penelitian ini menerapkan lima tahap dari sepuluh tahap yang dikemukakan Borg and Gall dengan alur berikut ini. (1) Research \& information collector untuk studi pendahuluan dengan langkah observasi dan wawancara untuk menghasilkan temuan sementara sebagai bahan penyusunan buku ajar. (2) Planning meliputi perancangan dan tahap pengembangan produk. (3) Develope premliminary form of product dengan kegiatan penyusunan $\mathrm{KI}, \mathrm{KD}$, tujuan dan materi ajar, silabus, RPP, pengembangan produk, uji validasi pada ahli sastra dan pembelajaran sastra, dan revisi pengembangan produk awal. (4) Preminary field testing dengan percobaan kepraktisan terhadap guru bahasa indonesia, dan uji kemenarikan serta keefektifan pada peserta didik kelompok kecil. (5) Revisi produk utama yakni revisi besar pada hasil percobaan utama dilakukan dengan cara menganalisis semua catatan, komentar, masukan, dan saran-saran dari uji validasi oleh para ahli, uji kepraktisan oleh guru, dan uji kemenarikan serta keefektifan oleh peserta didik. Adapun tahap diseminasi dengan memberikan produk kepada SMK sasaran dan menginformasikan kepada MGMP Bahasa Indonesia SMK di Kediri.

Penelitian ini melibatkan SMK di Kediri. Hal ini menyesuaikan daerah asal cerita Panji. Sasaran percobaan produk meliputi kumpulan: (1) pakar pengembang bahan ajar bidang sastra dan pembelajarannya, (2) kelompok percobaan di lapangan tahap awal untuk menilai kepraktisan produk yang diterapkan kepada guru bahasa Indonesia; dan (3) uji kemenarikan dan kefektifan dilakukan terhadap peserta didik kelas X. Model ini sesuai dengan konteks implementasi kurikulum terbaru Indonesia yang memberikan kewenangan guru mengembangkan bahan ajar dan akan melibatkan guru sebagai tim partisipatif 
dalam penyusunan sehingga dapat memberikan pengalaman kepada guru dalam menyusun buku ajar.

Pengumpulan data berupa instrumen yang terdiri atas lembar tes, angket, dan pedoman wawancara. Lembar tes digunakan untuk mengetahui keefektifan penggunaan buku ajar dari hasil tes uji kompetensi peserta didik. Angket ditujukan sebagai percobaan terhadap dua orang ahli yaitu ahli sastra dan pembelajaran sastra, siswa, dan guru. Adapun pedoman wawancara digunakan sebagai lembar klarifikasi berupa komentar dan saran.

Analisis data penelitian ini dengan teknik kualitatif dan kuantitatif sederhana. Data verbal yang diperoleh dari catatan tertulis dan wawancara berupa komentar tertulis pada angket digunakan sebagai data kualitatif. Data kuantitatif diperoleh dari angket penilaian bahan ajar.

Pengolahan data angket yang telah divalidasi dianalisis dengan rumus pengolah data per item $P=\frac{x}{x i} \times 100 \%$ dan pengolah data keseluruhan item $P=\frac{\sum x}{\sum x i} \times 100 \%$. Penafsiran hasil analisis data menggunakan interpretasi berdasarkan Sugiyono (2008: 417-421), yaitu (1) jika aspek buku ajar diuji kelayakannya mencapai presentase $86 \%$ - 100\%, maka buku ajar dapat dikualifikasikan sangat layak dan diimplementasikan,(2) jika aspek buku ajar diuji kelayakannya mencapai presentase $76 \%$ - 85\%, maka buku ajar dapat dikualifikasikan layak dan diimplementasikan, (3) jika aspek buku ajar diuji kelayakannya mencapai presentase 56\% - 75\%, maka buku ajar dapat dikualifikasikan cukup layak dan revisi, (4) jika aspek buku ajar diuji kelayakannya mencapai presentase $<55 \%$, maka buku ajar dapat dikualifikasikan kurang layak dan revisi.

Artikel ini memaparkan hasil penelitian pada aspek penyajian data uji ahli dan percobaan di lapangan.

\section{HASIL}

\section{Penyajian Data Uji Ahli dan Uji Coba Lapangan}

Produk bahan ajar Cerita Panji dengan pendekatan Content Language Integrated Learning (CLILL) untuk SMK ini dikembangkan melalui empat komponen. Empat komponen tersebut mencakup sistematika penyajian, isi, ragam bahasa, dan tampilan.

Uji kelayakan produk teks Cerita Panji bermuatan pendekatan Content Language Integrated Learning (CLIL) untuk siswa SMK kelas X dilakukan dengan empat langkah, yaitu (1) uji ahli sastra, (2) uji ahli pembelajaran sastra, (3) uji coba guru, dan (4) uji coba pada siswa. Uji ahli terhadap produk diterapkan kepada dua orang pakar. Uji coba produk dilakukan oleh dua orang guru, dan kelas X.

Pada lembar angket terdapat kriteria pemberian skor. Kriteria skor 1 menunjukkan bahwa bahan ajar kurang layak sehingga harus direvisi, skor 2 menunjukkan bahwa bahan ajar cukup layak namun harus direvisi, skor 3 menunjukkan bahwa bahan ajar layak sehingga layak diimplementasikan, dan skor 4 berart bahan ajar sangat layak diimplementasikan. Tindak lanjut yang 
dilakukan terhadap empat kriteria (implementasi/revisi) produk yang telah diujikan, data numerik hasil uji dipersentasikan sesuai dengan pedoman interpretasi kavalidan bahan ajar agar dapat diketahui tingkat kevalidannya. Data penelitian dan pengembangan dalam penelitian ini satu diantaranya menggunakan data kuantitatif. Data tersebut dideskripsikan sebagai berikut.

Data kuantitatif diperoleh dari hasil angket validasi dari yaitu (1) uji ahli sastra, (2) uji ahli pembelajaran sastra, (3) uji coba guru, dan (4) uji coba pada siswa. Komponen penilaian meliputi isi, sistematika penyajian, ragam bahasa, tampilan produk.

Komponen pertama yaitu isi. Penilaian komponen isi oleh ahli sastra memeroleh 82,5\%, sehingga komponen isi pada produk Pembelajaran Teks Cerita Panji dapat dikualifikasikan layak diimplementasikan dalam pembelajaran. Penilaian komponen isi oleh ahli pembelajaran sastra secara umum diperoleh hasil persentase $86,1 \%$, sehingga produk bahan ajar dinyatakan sangat layak untuk diaplikasikan. Revisi produk dilakukan berdasarkan catatan komentar dan saran pada angket. Selanjutnya, uji coba lapangan terhadap guru. Hasil data tersebut diperoleh bahwa komponen isi memeroleh skor dengan presentase rata-rata 90,62\%, sehingga pada komponen isi produk bahan ajar dinyatakan sangat layak untuk digunakan dalam pembelajaran siswa SMK. Pemerolehan data hasil uji coba lapangan pada siswa yaitu presentase rata-rata $100 \%$, sehingga komponen isi pada produk bahan ajar Pembelajaran Teks Cerita Panji dinyatakan sangat layak untuk diimplementasikan dalam pembelajaran teks cerita rakyat di SMK.

Komponen kedua yaitu sistematikan penyajian. Penilaian komponen sistematikan penyajian oleh ahli sastra diperoleh hasil skor dengan presentase 100 $\%$, artinya produk komponen ini dinyatakan sungguh layak untuk diterapkan dalam pembelajaran. Penilaian komponen sistematikan penyajian oleh ahli pembelajaran sastra terhadap produk bahan ajar menunjukkan hasil skor dengan presentase $100 \%$, sehingga produk pada komponen ini dinyatakan sungguh layak untuk digunakan. Selanjutnya dilakukan revisi terhadap produk bahan melalui catatan yang diberikan oleh ahli pembelajaran sastra. Setelah revisi dan diperoleh data hasil uji coba lapangan oleh guru pada penilaian sistematika dengan presentase rata-rata $93,75 \%$, sehingga pada komponen sistematika penyajian dinyatakan sangat layak diimplementasikan untuk pembelajaran. Setelah dilakukan revisi komponen sistematika penyajian pada produk bahan ajar , diperoleh skor dengan presentase rata-rata 95\% dari uji coba lapangan terhadap peserta didik SMK. Presentase tersebut menunjukkan bahwa produk bahan ajar Pembelajaran Teks Cerita Panji sangat layak diimplementasikan dalam pembelajaran sastra di sekolah.

Komponen ketiga yaitu ragam bahasa. Penilaian komponen ragam bahasa dilakukan dengan uji ahli dan uji coba lapangan. Komponen ragam bahasa dari uji ahli sastra menunjukkan skor dengan presentase rata-rata $100 \%$, sehingga pada komponen ragam bahasa produk bahan ajar ini dinyatakan sangat layak untuk diterapkan dalam pembelajaran di SMK. Penilaian komponen ragam bahasa oleh ahli pembelajaran sastra menunjukkan presentase 91,67 \%, sehingga pada komponen ragam bahasa produk bahan ajar dinyatakan sangat layak digunakan dalam pembelajaran teks cerita rakyat di SMK. Hasil percobaan di lapangan oleh

31 BRILIANT: Jurnal Riset dan Konseptual Volume 5 Nomor 1, Februari 2020 
guru bahasa Indonesia SMK menunjukkan presntase 93,58\%, sehingga guru menyatakan bahwa produk bahan ajar komponen ragam bahasa sangat layak diterapkan dalam pembelajaran sastra di SMK. Setelah dilakukan revisi, selanjutnya didapatkan hasil data percobaan di lapangan pada siswa kelas $\mathrm{X}$ SMKN 1 Semen. Setelah dilakukan revisi terhadap komponen ragam bahasa, hasil uji coba lapangan pada siswa menunjukkan presentase $95 \%$, sehingga produk bahan ajar Pembelajaran Teks Cerita Panji komponen ragam bahasa sangat layak diterapkan dalam pembelajaran sastra di SMK.

Komponen keempat yaitu tampilan. Penilaian komponen tampilan dilakukan oleh ahli sastra, ahli pembelajaran sastra, guru, dan siswa. Ahli sastra menilai komponen tampilan produk bahan ini dengan presentase rata-rata 77,78\%, sehingga dinyatakan produk bahan ajar layak diimplementasikan dalam pembelajaran. Penilaian komponen tampilan oleh ahli pembelajaran sastra diperoleh skor dengan presentase 83,3\%, sehingga pada kompone tampilan produk bahan ajar dinyatakan layak diterapkan dalam pembelajaran sastra di SMK. Setelah dilakukan revisi terhadap komponen tampilan, ditemukan hasil percobaan lapangan. Percobaan di lapangan oleh guru bahasa Indonesia SMK menunjukkan presntase $85,94 \%$, sehingga guru menyatakan bahwa produk bahan ajar komponen tampilan layak diterapkan dalam pembelajaran sastra di SMK. Setelah dilakukan revisi komponen tampilan pada produk bahan ajar diperoleh skor dengan presentase rata-rata $86,25 \%$, sehingga produk bahan ajar Pembelajaran Teks Cerita Panji komponen ragam bahasa sangat layak diterapkan dalam pembelajaran sastra di SMK.

\section{PEMBAHASAN}

Hasil analisis data menunjukkan bahwa produk bahan ajar Pembelajaran Teks Cerita Panji memenuhi kriteria kelayakan. Namun, pada komponenkomponen tertentu terdapat hal yang harus direvisi untuk mencapai unsur kelayakan yang optimal terhadap produk. Berikut pembahasan bagian produk yang telah direvisi.

\section{Hasil Pengkajian Revisi Produk}

Hasil produk bahan ajar Pembelajaran Teks Cerita Panji- Suatu Bahan Ajar Berbasis Content Language Integrated Learning (CLIL). Bahan ajar ini diimplementasikan dalam pembelajaran teks cerita hikayat pada kelas X di SMK. Produk ini dikembangkan berdasarkan empat komponen yaitu isi, sistematika penyajian, ragam bahasa, dan tampilan.

Komponen pertama yaitu isi. Isi bahan ajar memenuhi kriteria keterpaduan bahan belajar dengan $\mathrm{KI}$ dan $\mathrm{KD}$, pengembangan materi, kebenaran materi, kedalaman materi, serta kelengkapan bahan. Hal ini sesuai dengan pernyataan Masnur Muslich (2013:3) bahwa terdapat tiga indikator dalam kalayakan isi, meliputi kepaduan paparan bahan materi dengan $\mathrm{KD}$, kebenaran bahan, bahan pendukung belajar siswa. Berdasarkan hasil uji validasi dan uji coba lapangan, isi bahan ajar Pembelajaran Teks Cerita Panji- Suatu Bahan Ajar Berbasis Content Language Integrated Learning (CLIL) telah layak diimplementasikan. Materi yang telah layak diimplementasikan tersebut berupa aktivitas literasi dengan membaca artikel pada majalah yang diterbitkan 
Universitas Negeri Yohgyakarta, apersepsi berupa pembangunan konteks berupa pengantar Cerita Panji, teori tentang nilai, isi, karakteristik, dan keterampilan menceritakan kembali cerita hikayat berupa Hikajat Pandji Kuda Semirang, contoh-contoh mengientifikasi teks, dan latihan sesuai dengan Indikator Pencapaian Kompetensi (IPK) yang telah disusun.

Komponen kedua yaitu sistematika penyajian. Sistematika penyajian memuat enam komponen utama alam bahan ajar, yaitu tinjauan kompetensi, pendahuluan, unit inti, penutup, aftar pustaka, serta lampiran (Pannen dan Purwanto, 2001:2). (1) Tinjauan kompetensi dalam bahan ajar Pembelajaran Teks Cerita Panji- Suatu Bahan Ajar Berbasis Content Language Integrated Learning (CLIL) berupa petunjuk belajar untuk siswa dan cakupan tujuan belajar, kegiatan belajar, dan tugas -tugas yang dirinci melalui peta konsep sehingga siswa mampu merumuskan cakupan pembelajaran di awal. (2) Pendahuluan dalam bahan ajar ini memuat pengantar belajar berupa aktivitas literasi dan pembangunan konteks. Aktivitas literasi yang dilakukan dengan menyediakan waktu 15 menit untuk membaca artikel dengan dilanjutkan dengan mengurai isi artikel tersebut melalui kegiatan meresume secara tertulis. Adapun pembangunan konteks, bahan ajar ini menyajikan pengantar Cerita Panji. Hal ini bertujuan untuk mengingatkan pengetahuan siswa SMK terhadap budaya lokal di Kediri, khususnya pada siswa yang telah meninggalkan budaya lokalnya. (3) Bagian inti bahan ajar Pembelajaran Teks Cerita Panji-Suatu Bahan Ajar Berbasis Content Language Integrated Learning (CLIL) berupa kegiatan inti yang dikembangkan berdasarkan pendekatan CLIL. Pendekatan tersebut memuat konten dan kultur dengan menghadirkan Cerita Panji, komunikasi dengan penceritaan ulang, dan kognisi berkaitan dengan kompetensi yang dicapai dalam IPK yaitu mengidentifikasi nilai-nilai, isi pokok, dan karakteristik. Paduan aspek pengetahuan dan keterampilan dimuat dalam bahan ajar ini secara sistematis. (4) Kegiatan penutup disajikan dengan memberikan kesempatan kepada siswa mengulang kembali bagian pembelajaran yang belum dikuasai. Bagian ini, siswa dapat berkonsultasi dengan orangtua, guru, teman, atau orang lain sebagai bagian sumber belajar. Selanjutnya siswa diminta memberikan uraian tentang kegiatan belajar yang telah dilakukan (kesan) dan saran pembelajaran. (5) daftar pustaka mencakup sejumlah rujukan untuk mengembangkan bahan.

Komponen ketiga yaitu bahasa. Komponen bahasa pada bahan ajar ini menyesuaikan dengan perkembangan bahan siswa SMK. Hal yang diperhatikan dalam menggunakan bahasa pada bahan ajar ini berupa (1) kemampuan berbahasa siswa, (2) kaidah bahasa, (3) pilihan kata, (4) gaya bahasa, (5) keterbacaan (B.P. Sitepu, 2012: 108). Kelima aspek tersebut diterapkan dalam penyusunan bahan ajar sesuai engan kemampuan bahasa siswa SMK. Tahapan pembelajaran disusun dengan bahasa yang komunikatif agar siswa SMK dengan mudah menafsirkan pembelajaran. Namun, pada bagian ini siswa kesulitan dalam memahami teks hikayat. Hal ini dikarenakan, bahasa hikayat pada teks Hikajat Pandji Kuda Semirang terdapat perbedaan dengan bahasa Indonesia yang dikuasai, namun tidak menjadi faktor utama kesulitan siswa memahami bahasa terhadap teks hikayat.

33 BRILIANT: Jurnal Riset dan Konseptual Volume 5 Nomor 1, Februari 2020 
Komponen keempat yaitu tampilan. Kemenarikan suatu bahan ajar satu diantaranya dapat dilihat dari kegrafikan atau tampilan bahan ajar. Bahan ajar Pembelajaran Teks Cerita Panji-Suatu Bahan Ajar Berbasis Content Language Integrated Learning (CLIL) disajikan dengan komposisi yang menarik sesuai dengan usia pengguna bahan ajar. Ilustrasi juga disajikan pada bagian-bagian tertentu dalam bahan ajar ini. Hal ini sesuai dengan pendapat pakar bahwa penggunaan buku teks henaklah menarik minat peserta didik (Muslich, 2010:53). Adapun ampilan terkait tata letak bahan ajar ini yaitu dicetak dengan ukuran kertas A5 70 gram, tata letak disesuaikan dengan proporsional margin dengan meletakkan halaman di bagian bawah. Jenis huruf yang dipakai dalam produk mencakup beberapa font face. Font face pada kata pengantar, petunjuk belajar, daftar isi, pengantar belajar, kegiatan inti, penutup, daftar pustaka memakai times new roman ukuran $12 \mathrm{pt}$. Komposisi warna pada bahan ajar ini terdiri atas coklat muda, krem, dan merah. Hal ini dengan mempertimbangan aspek klasik sesuai dengan tema atau isi pembelajaran, yaitu Cerita Panji.

\section{KESIMPULAN}

Penelitian memproduksi bahan ajar yang dikemas dengan judul Pembelajaran Teks Cerita Panji-Suatu Bahan Ajar Berbasis Content Language Integrated Learning (CLIL). Bahan ajar ini dapat menjadi alternatif pembelajaran sastra di SMK yang memuat kearifan budaya lokal wilayah Kediri, Jawa Timur yaitu melalui Cerita Panji.

Kelayakan produk ini didasarkan pada penilaian dari pakar sastra, pembelajaran sastra, guru, dan siswa SMK. Penilaian terdiri atas komponen isi, sistematika penyajian, ragam bahasan, dan tampilan produk. Berdasarkan hasil analisis ata, produk Pembelajaran Teks Cerita Panji- Suatu Bahan Ajar Berbasis Content Language Integrated Learning (CLIL) layak digunakan untuk pembelajaran bahasa indonesia pada teks cerita rakyat kelas X SMK.

\section{SARAN}

Bahan ajar teks cerita Panji untuk SMK kelas X layak dipakai dalam pembelajaran sastra, khususnya mengidentifikasi nilai-nilai Cerita Panji. Produk bahan ajar ini menyajikan cerita rakyat Jawa Timur yang jarang ditemui peserta didik. Tahapan pembelajaran produk ini tidak sukar dipelajari peserta didik. Oleh karena itu, dalam memanfaatan bahan ajar ini peserta didik disarankan mengikuti prosedur pembelajaran dalam bahan ajar.

Prosedur penelitian pengembangan bahan ajar cerita Panji untuk SMK kelas $\mathrm{X}$ bermuatan CLIL dapat menjadi pedoman bagi peneliti lain dalam menerapkan penelitian serupa dan atau kompetensi dasar yang lain. Selain itu, penelitian lanjutan dapat dilaksanakan dengan metode $R \& D$ hingga tahap akhir atau tahap kesepuluh.

Hasil pengembangan produk bahan ajar teks cerita Panji merupakan alternatif belajar yang memudahkan guru dan siswa dalam pembelajaran mengidentifikasi nilai-nilai kehidupan dan budaya masyarakat. Selain itu, produk ini hendaknya dapat dimanfaatkan secara maksimal dalam pembelajaran di SMK. Jika produk ini telah dimanfaatkan oleh semua pihak, maka peneliti akan 
memeroleh saran perbaikan untuk dikembangkan pada masa akan datang. Pengembangan produk lanjutan dapat dilakukan oleh guru secara mandiri, penulis buku, atau lembaga pemerintah melalui Pusat Perbukuan. Produk-produk tersebut akan memenuhi kebutuhan pembelajaran bahasa Indonesia dan budaya kearifan lokal.

\section{DAFTAR RUJUKAN}

Haryani, Darwanti Dwi. (2018). Pembelajaran Menulis Cerpen dengan Pemanfaatan Media Video Lukisan Pasir melalui Teknik Transformasi. Dalam Stilistika: Kajian Bahasa, Sastra, dan Pembelajarannya, Volume 4 Nomor 1, hlm. 13-22.

Suherli, Maman S., Aji S., \& Istiqomah. (2012). Bahasa Indonesia: Buku Guru Edisi Revisi. Jakarta: Kementerian Pendidikan dan Kebudayaan RI.

Manuaba, Ida B.P., Aji S. \& Puji K. (2013). Keberadaan Bentuk Transformasi Cerita Panji. LITERA: Jurnal Penelitian Bahasa, Sastra, dan pengajarannya. Volume 12 Nomor 1 April 2013.

Muslich, M. (2010). Text Book Writing: Dasar-dasar Pemahaman, Penulisan, dan Pemakaian Buku Teks. Jogjakarta: Ar-Ruzz Media.

Pannen, P. \& Purwanto. (2001). Penulisan Bahan Ajar. Jakarta: Pusat AntarUniversitas untuk Peningkatan dan Pengembangan Aktivitas Intruksional Direktorat Jenderal Perguruan Tinggi

Sitepu, B.P. (2012). Penulisan Buku Teks Pelajaran. Bandung: Remaja Rosdakarya.

Sugiyono. 2014. Metode Penelitian Pendidikan: Pendekatan Kuantitatif,

Kualitatif, dan $R \& D$. Bandung: Alfabeta.

Vázquez, Víctor P., \& Maria E. (2013). Examining Teacher Roles And Competences In Content And Language Integrated Learning (Clil). Linguarum Arena: Revista De Estudos Em Didática De Línguas Da Universidade Do Porto, Vol. 4: 65 - 78. 